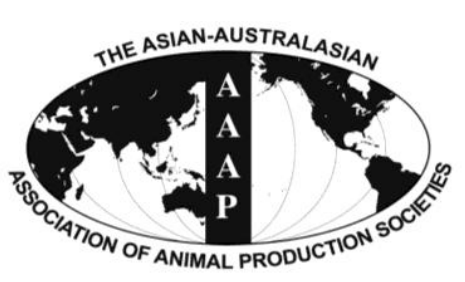

Open Access

Asian Australas. J. Anim. Sci.

Vol. 27, No. 8 : 1181-1188 August 2014

http://dx.doi.org/10.5713/ajas.2013.13729

www.ajas.info

pISSN 1011-2367 elSSN 1976-5517

\title{
Identification of Differentially Expressed Proteins in Liver in Response to Subacute Ruminal Acidosis (SARA) Induced by High-concentrate Diet
}

\author{
X. Y. Jiang, Y. D. Ni, S. K. Zhang, Y. S. Zhang*, and X. Z. Shen \\ College of Veterinary Medicine, Nanjing Agricultural University, Nanjing 210095, China
}

\begin{abstract}
The aim of this study was to evaluate protein expression patterns of liver in response to subacute ruminal acidosis (SARA) induced by high-concentrate diet. Sixteen healthy mid-lactating goats were randomly divided into 2 groups and fed either a high-forage (HF) diet or a high-concentrate (HC) diet. The HC diet was expected to induce SARA. After ensuring the occurrence of SARA, liver samples were collected. Proteome analysis with differential in gel electrophoresis technology revealed that, 15 proteins were significantly modulated in liver in a comparison between HF and HC-fed goats. These proteins were found mainly associated with metabolism and energy transfer after identified by matrix-assisted laser desorption ionization/time of flight. The results indicated that glucose, lipid and protein catabolism could be enhanced when SARA occurred. It prompted that glucose, lipid and amine acid in the liver mainly participated in oxidation and energy supply when SARA occurred, which possibly consumed more precursors involved in milk protein and milk fat synthesis. These results suggest new candidate proteins that may contribute to a better understanding of the mechanisms that mediate liver adaptation to SARA. (Key Words: Liver, Metabolism, High-concentrate, Subacute Ruminal Acidosis [SARA])
\end{abstract}

\section{INTRODUCTION}

In intensive ruminant livestock systems, rapidly fermentable (high grain) diets are commonly utilized to increase energy intake or simply due to a lack of forages at times in China. When ruminants are fed high-grain diets, short chain fatty acid (SCFA) production can exceed absorption and ruminal $\mathrm{pH}$ becomes depressed which can cause ruminal acidosis (Bergman, 1990; DeVries et al., 2009). Subacute ruminal acidosis (SARA), which is diagnosed when ruminal $\mathrm{pH}$ falls below 5.6 for more than 3 $\mathrm{h}$ per day, is common in practical dairy production (Gozho et al., 2005; AlZahal et al., 2007). As a common digestive disorder occurring in ruminants, the consequences of SARA include feed intake depression, reduced fiber digestion, milk fat depression, diarrhea, laminitis (Nocek, 1997; Stone, 2004), liver abscesses, rumen mucosal damage (Kleen et al.,

\footnotetext{
* Corresponding Author: Y. S. Zhang. Tel: +86-2584396763, E-mail: zhangyuanshu@ njau.edu.cn

Submitted Nov. 16, 2013; Revised Jan. 20, 2014; Accepted Mar. 4, 2014
}

2003), increased production of bacterial endotoxin and inflammation characterized by increases in acute phase proteins (AlZahal et al., 2007).

Liver is the largest and complex digestive gland in ruminant animals, which is involved in the digestion, absorption, excretion, detoxification, material transportation, energy metabolism and immunity. Nutrients absorbed from digestive tract in dairy cows must pass through liver, and then enter into circulatory system, arrive at mammary gland; therefore, liver plays an important role in nutrient composition of peripheral blood and metabolic integration regulation. Although the physiopathology of SARA has been comprehensively studied (Nocek, 1997; Kleen et al., 2003), there are few reports describing the hepatic metabolic adaption when SARA occurs. Two-dimensional gel electrophoresis (2-DE) is a holistic protein characterization method that might help to decipher proteomic changes in the goat liver. Therefore, the first objective of this study was to develop and characterize a nutritional model for inducing SARA. The second objective was to determine global protein expression changes in the

Copyright $@ 2014$ by Asian-Australasian Journal of Animal Sciences This is an open-access article distributed under the terms of the Creative Commons Attribution Non-Commercial License (http://creativecommons.org/licenses/by-nc/3.0/), which permits unrestricted non-commercial use, distribution, and reproduction in any medium, provided the original work is properly cited. 
liver in response to SARA.

\section{MATERIALS AND METHODS}

\section{Materials}

Immobilized $\mathrm{pH}$ gradient (IPG) strips ( $\mathrm{pH} 3.0$ to 10.0 non-linear (NL); $17 \mathrm{~cm})$, urea, thiourea, dithiothreitol (DTT), 3-([3-cholamidopropyl] dimethyl-ammonio)-1propane sulfonate (CHAPS), ampharmalyte $\mathrm{pH} 3$ to 10 , phenylmethane sulfonyl fluoride (PMSF), iodoacetamide (IAM) were purchased from Bio-Rad (Richmond, CA, USA). Coomassie brilliant blue G-250 was purchased from AMRESCO (Solon, OH, USA). All chemicals for sodium dodecyl sulphate-polyacrylamide gel electrophoresis (SDSPAGE) were of electrophoresis grade.

\section{Animals and liver sampling}

Sixteen mid-lactating Boer crossbred goats (obtained from Zhejiang, China) with rumen fistula, weighed $46.90 \pm 3.14 \mathrm{~kg}$, were randomly divided into 2 groups. The experiment periods were 3 weeks in duration following a 14-day adaptation. The animals were fed either a highforage (HF) diet or a high-concentrate (HC) diet. Goats were fed and milked twice daily (8:00 and 18:00). The HC diet composition was selected to induce SARA (Brossard et

Table 1. Composition and nutrient levels of experimental diets $(\%)$

\begin{tabular}{lcc}
\hline Item & $\mathrm{HF}$ & $\mathrm{HC}$ \\
\hline Ingredient $(\%)$ & 48 & 32 \\
Hay & 12 & 8 \\
Alfalfa & 29.2 & 23.07 \\
Corn & 0 & 28.3 \\
Wheat bran & 8.43 & 2 \\
Soybean meal & 0 & 3.7 \\
Rapeseed meal & 0.57 & 1.43 \\
Limestone & 0.9 & 0.6 \\
CaHPO & & 0.4 \\
Salt & 0.4 & 0.5 \\
Premix & \\
Nutrient level $(\%)$ & 0.5 & \\
ME, KJ/kg & & 17,828 \\
$\mathrm{CP}$ & 18,012 & 15.38 \\
Fat & 14.21 & 3.44 \\
$\mathrm{NDF}$ & 3.47 & 50.81 \\
$\mathrm{ADF}$ & 60.23 & 17.29 \\
$\mathrm{Ca}$ & 23.02 & 1.18 \\
$\mathrm{P}$ & 0.99 & 0.46 \\
\hline
\end{tabular}

HF, high-forage; $\mathrm{HC}$, high- concentrate; ME, metabolizable energy; $\mathrm{CP}$, crude protein; $\mathrm{NDF}$, neutral detergent fiber; $\mathrm{ADF}$, acid detergent fiber.

${ }^{1}$ Premix group was divided into: $\mathrm{FeSO}_{4} \cdot 7 \mathrm{H}_{2} \mathrm{O} 170 \mathrm{~g} / \mathrm{kg} ; \mathrm{CuSO}_{4} \cdot 5 \mathrm{H}_{2} \mathrm{O} 70$ $\mathrm{g} / \mathrm{kg} ; \mathrm{MnSO}_{4} \cdot 5 \mathrm{H}_{2} \mathrm{O} 290 \mathrm{~g} / \mathrm{kg} ; \mathrm{ZnSO}_{4} \cdot 7 \mathrm{H}_{2} \mathrm{O} 240 \mathrm{~g} / \mathrm{kg} ; \mathrm{Co}_{2} \mathrm{Cl} \cdot 6 \mathrm{H}_{2} \mathrm{O} 510$ $\mathrm{mg} / \mathrm{kg} ; \mathrm{KI} 200 \mathrm{mg} / \mathrm{kg} ; \mathrm{NaSeO}_{3} 130 \mathrm{mg} / \mathrm{kg}$; vit A 1,620,000 IU/kg; vit $\mathrm{D}_{3}$ $324,000 \mathrm{IU} / \mathrm{kg}$; vit E $540 \mathrm{IU} / \mathrm{kg}$; vit $\mathrm{K}_{3} 150 \mathrm{mg} / \mathrm{kg}$; vit $\mathrm{B}_{12} 0.9 \mathrm{mg} / \mathrm{kg}$; vit $\mathrm{B}_{5} 450 \mathrm{mg} / \mathrm{kg}$; calcium pantothenate $750 \mathrm{mg} / \mathrm{kg}$; folic acid $15 \mathrm{mg} / \mathrm{kg}$. al., 2003). Composition and nutrient levels of experimental diets are given in Table 1. All goats were housed in individual stalls and had free access to drinking water. The animal care and use protocol was approved by the Institutional Animal Care and Use Committee of Nanjing Agricultural University.

Ruminal liquid samples $(10 \mathrm{~mL})$ were taken from the ventral sac of the rumen before morning feeding and at 1,2 , 4,6 , and $10 \mathrm{~h}$ after feeding of the last 2 days. The $\mathrm{pH}$ of the rumen fluid was immediately determined by means of a portable $\mathrm{pH}$ meter (HI8424, Hana Instruments, Milan, Italy). When rumen $\mathrm{pH}$ was depressed for prolonged periods each day, e.g. below 5.6 for over $3 \mathrm{~h} / \mathrm{d}$, SARA was induced successfully. After ensuring the occurrence of SARA, liver samples were collected at the 3rd day. Samples were collected directly after goats were sacrificed and stored at $80^{\circ} \mathrm{C}$.

\section{Protein sample preparation and 2-D gel electrophoresis}

Two-dimensional gel electrophoresis (2-DE) was performed on both HF and HC groups with the method as previously described by Chen et al. (2010). Tissues were homogenized in lysis buffer consisting of $7 \mathrm{M}$ urea, $2 \mathrm{M}$ thiourea, 2\% (w/v) CHAPS, $50 \mathrm{mM}$ DTT, 0.8\% (w/v) ampharmalyte $\mathrm{pH} 3$ to 10 and $1 \mathrm{mM}$ PMSF using a glass homogenization vessel in ice bath. The resulting homogenates were swirled for $30 \mathrm{~min}$ followed by a $30 \mathrm{~min}$ centrifugation at $15,000 \mathrm{~g}$ at $4^{\circ} \mathrm{C}$. Supernatants were collected and fractionated in aliquots. Protein concentrations of the final supernatants were measured using bovine serum albumin (BSA) as standard by the Bradford assay (Bradford, 1976).

To ensure reproducibility, the goat liver extract was pooled and run under the same conditions to overcome inter-individual changes in animals. All 2-DE gels were run three times. In brief, protein concentration of the lysate was adjusted to $850 \mu \mathrm{g} / 320 \mu \mathrm{L}$ volume of rehydration buffer and the lysate was applied onto IPG strips (pH 3.0 to $10.0 \mathrm{NL}$; $17 \mathrm{~cm}$ ) in the protean system (Bio-Rad, Hercules, CA, USA). After $13 \mathrm{~h}$ of passive rehydration in the tray, isoelectric focusing was performed with the following programmed voltage parameters: $250 \mathrm{~V}$ for $1 \mathrm{~h}, 500 \mathrm{~V}$ for 1 $\mathrm{h}, 2,000 \mathrm{~V}$ for $1 \mathrm{~h}, 8,000 \mathrm{~V}$ for $3 \mathrm{~h}$, and then holding at $8,000 \mathrm{~V}$ until a total of at least $60,000 \mathrm{~V}$-h was reached. Then strips were equilibrated with DTT and iodoacetamide. The second dimension was run on a $12.5 \%$ polyacrylamide SDS gel $(26 \times 20 \mathrm{~cm})$ at $16^{\circ} \mathrm{C}$ using Multiphor system $(15$ $\mathrm{W} / \mathrm{gel}$ ) (Amersham Biosciences, Uppsala, Sweden) until the bromophenol blue dye had reached the bottom of the gel. Then Neuhoff's colloidal Coomassie blue G-250 stain was carried out according to the method described by Candiano et al. (2004).

Stained gels were scanned with a high precision scanner 
(Versa Doc 3000, Bio-Rad, Hercules, CA, USA) and analyzed using PDQuest8.1.0 software (Bio-Rad, Hercules, CA, USA). After alignment, spots between gels were automatically matched first. The matched spots were reexamined manually to ensure accuracy. Generally, only those spots of more than 3-fold difference in both dietary modes were chosen for further analysis. Spot quantity normalization was conducted in the 'total quantity valid spots' mode.

\section{Matrix-assisted laser desorption ionization/time of flight analysis}

The differentially expressed protein spots were excised from gels and conserved in Ependoff tubes, followed by matrix-assisted laser desorption ionization/time of flight analysis which was carried out by BoYuan Biological Technology Company in Shanghai, China. Protein digested by trypsin was used to calibrate the mass instrument using the internal calibration mode. Parent mass peaks had a mass range of 800-3,500 Da. Protein data searches were performed by search engine of Mascot.

\section{RESULTS}

\section{Dynamic change of ruminal pH}

The $\mathrm{pH}$ data were expressed as mean \pm standard deviation, and differences were considered significant when $\mathrm{p}<0.05$, which were tested by one-way analysis of variance (ANOVA) followed by a multiple range test using SPSS16.0 software (SPSS, Chicago, IL, USA). As expected, goats fed the HF diet displayed steady ruminal $\mathrm{pH}$ traces

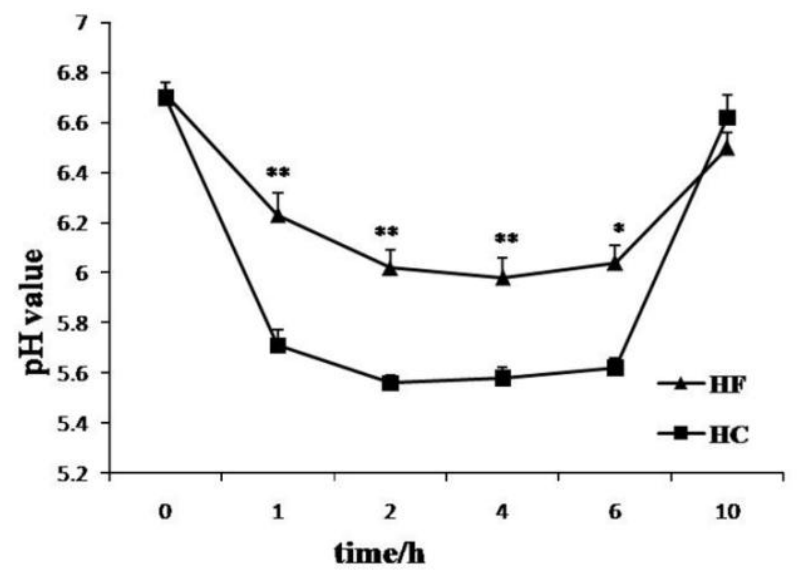

Figure 1. Effect of different forage to concentrate ratio diet on $\mathrm{pH}$ changes in rumen in lactating goats. Treatment consisted of HF (घ) and HC ( $\boldsymbol{\Delta})$ for 3 weeks. The ruminal liquid samples $(10 \mathrm{~mL})$ were taken from the ventral sac of the rumen through a cannula at before feeding and at 1, 2, 4, 6, $10 \mathrm{~h}$ after the morning feeding at the end of experiment. The $\mathrm{pH}$ of the rumen fluid was immediately determined by means of a portable $\mathrm{pH}$ meter. $*$ and ** indicate significant $(\mathrm{p}<0.05)$ or markedly significant $(\mathrm{p}<0.01)$ differences between 2 groups $(\mathrm{n}=8)$. HF, high-forage; HC, highconcentrate.

with no hours below pH 5.6 (Figure 1). In contrast, SARA was diagnosed in the $\mathrm{HC}$ group as ruminal $\mathrm{pH}$ was depressed below 5.6 for about $4 \mathrm{~h}$ (Figure 1).

\section{Comparison of proteomic patterns}

We performed comparative visual and software-guided analysis of representative 2-DE proteome profiles of the 2 groups. There was good separation of protein spots seen in

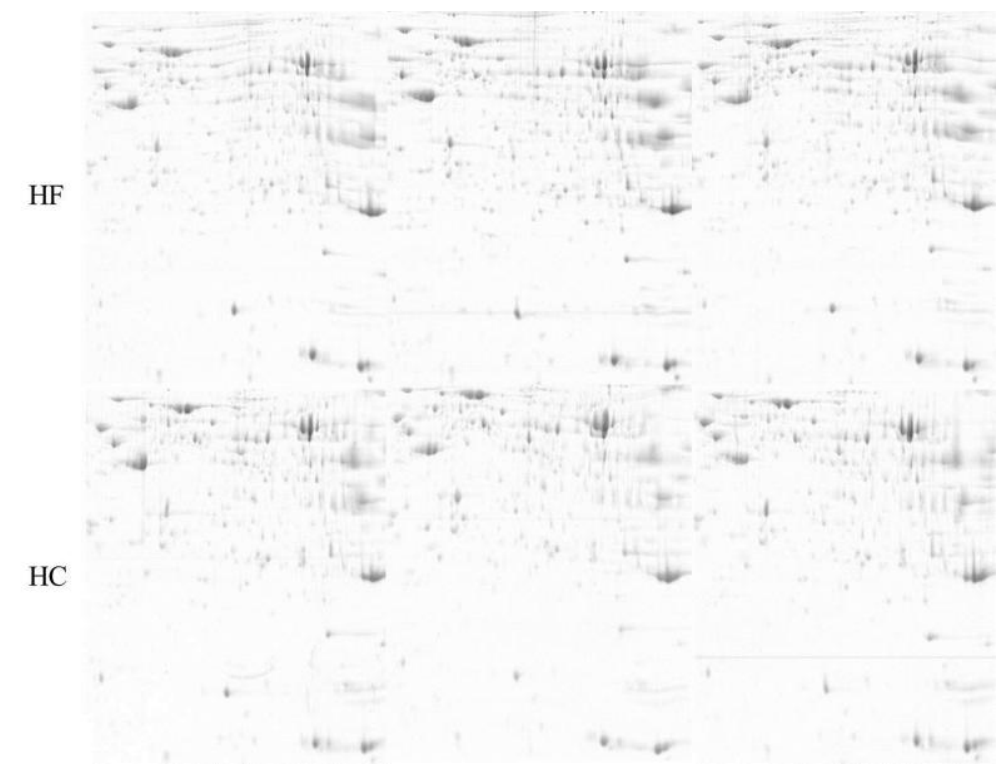

Figure 2. Representative spot maps of HF and HC groups. HF stands for high-forage and HC stands for high-concentrate. Equal amounts

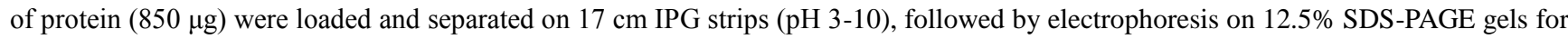
second dimension electrophoresis. The gels were stained with CCB G250. IPG, Immobilized pH gradient; SDS-PAGE, sodium dodecyl sulphate-polyacrylamide gel electrophoresis. 


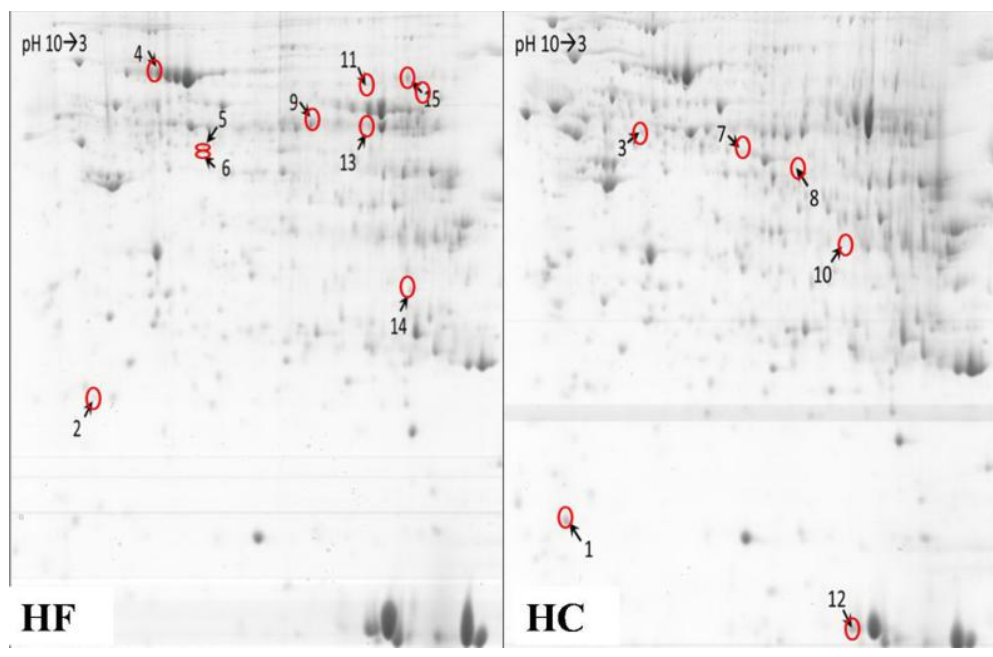

Figure 3. Effect of different forage to concentrate ratio diet on the protein/enzyme profiles of liver. The HC diet (diet forage to concentrate ratios was 60:40) was selected to induce subacute ruminal acidosis (SARA) with mid-lactating goats. After SARA occurred, the 3rd day liver samples were collected. The total liver proteins of 2 groups were extracted and separated by 2-DE (two dimensional gel electrophoresis). The arrows indicate the proteins with at least 3.0-fold change. HF, high-forage; HC, high- concentrate.

the 2-D gel electrophoresis except in the base area (Figure 2). After auto-matching and manual quality check of the detected spots, $495 \pm 23$ valid spots were identified in this experiment series.

In general, the protein profiles of the 2 feeding conditions detected by 2 -DE were similar to each other, suggesting that few proteins were differentially expressed in the two groups. A total of 15 protein spots, however, showed up to a 3-fold difference in volume when comparing the 2 groups (Figure 3). Positive identifications were obtained for these 15 spots, including 10 up-regulated and 5 down-regulated in SARA group, and protein identities of the 15 spots are listed in Table 2 .

In order to assess functional relevance of changes in the differentially expressed proteins, the proteins were classified according to their primary functions. These proteins were mainly related to metabolism and energy transfer. When SARA was induced, acyl-CoA synthetase (ACS) and cytochrome b5 involved in lipid metabolism were up-regulated, phosphoenolpyruvate carboxykinase (PEPCK) involved in glucose metabolism was downregulated, while enolase was up-regulated. At the aspect of

Table 2. MAIDI-TOF/TOF identification of differentially expressed proteins in liver in response to SARA

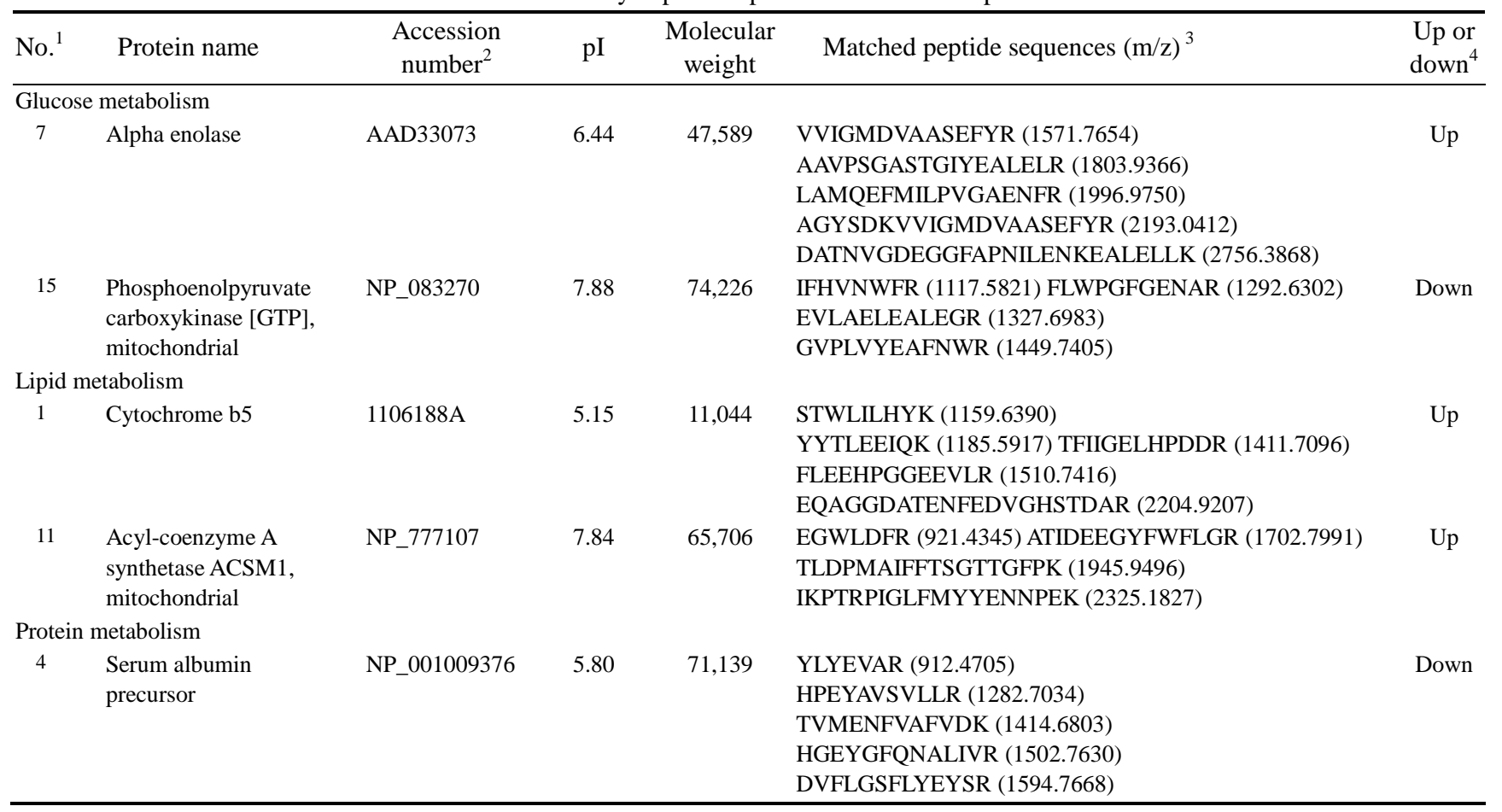


Table 2. MAIDI-TOF/TOF identification of differentially expressed proteins in liver in response to SARA (Continued)

\begin{tabular}{|c|c|c|c|c|c|c|}
\hline No. ${ }^{1}$ & Protein name & $\begin{array}{l}\text { Accession } \\
\text { number }\end{array}$ & $\mathrm{pI}$ & $\begin{array}{c}\text { Molecular } \\
\text { weight }\end{array}$ & Matched peptide sequences $(\mathrm{m} / \mathrm{z})^{3}$ & $\begin{array}{l}\text { Up or } \\
\text { down }\end{array}$ \\
\hline \multicolumn{7}{|c|}{ Protein metabolism } \\
\hline 5 & Adenosylhomocysteinase & NP_001029487 & 5.88 & 48,120 & $\begin{array}{l}\text { IILLAEGR }(883.5491) \\
\text { AGIPVYAWK }(1003.5491) \\
\text { YPQLLSGIR }(1045.5920) \\
\text { WLNENAVEK }(1101.5454) \\
\text { VADISLAAWGR }(1157.6193) \text { EGPFKPDHYRY }(1407.6571) \\
\text { GISEETTTGVHNLYK }(1647.8104)\end{array}$ & Up \\
\hline 6 & $\begin{array}{l}26 \mathrm{~S} \text { protease regulatory } \\
\text { subunit } 7\end{array}$ & NP_150239 & 5.59 & 48,943 & $\begin{array}{l}\text { DIRFELLAR }(1131.6400) \\
\text { FDDGAGGDNEVQR (1378.5750) } \\
\text { KIEFSLPDLEGR }(1402.7456) \\
\text { LREVVETPLLHPER }(1686.9417)\end{array}$ & Down \\
\hline 8 & $\begin{array}{l}\text { Elongation factor } \mathrm{Tu}, \\
\text { mitochondrial precursor }\end{array}$ & NP_776632 & 6.72 & 49,709 & $\begin{array}{l}\text { YEEIDNAPEER }(1363.5891) \\
\text { QIGVEHVVVYVNK }(1482.8195) \\
\text { LLDAVDTYIPVPTR }(1571.8559) \\
\text { DLEKPFLLPVESVYSIPGR }(2158.1674)\end{array}$ & Up \\
\hline 13 & $\begin{array}{l}\text { Glutamate } \\
\text { dehydrogenase } 1, \\
\text { mitochondrial }\end{array}$ & XP_001925088 & 8.03 & 61,668 & $\begin{array}{l}\text { NLNHVSYGR (1058.5257) } \\
\text { DDGSWEVIEGYR (1424.6208) } \\
\text { HGGTIPIVPTAEFQDR (1736.8846) } \\
\text { DSNYHLLMSVQESLER (1935.8996) } \\
\text { ELEDFKLQHGTILGFPK (1971.0466) } \\
\text { KGFIGPGIDVPAPDMSTGER (2059.0045) }\end{array}$ & Up \\
\hline \multicolumn{7}{|c|}{ Electron transfer } \\
\hline 1 & Cytochrome b5 & $1106188 \mathrm{~A}$ & 5.15 & 11,044 & $\begin{array}{l}\text { STWLILHYK (1159.6390) } \\
\text { YYTLEEIQK (1185.5917) TFIIGELHPDDR (1411.7096) } \\
\text { FLEEHPGGEEVLR (1510.7416) } \\
\text { EQAGGDATENFEDVGHSTDAR (2204.9207) }\end{array}$ & Up \\
\hline 9 & Retinal dehydrogenase 1 & NP_001009778 & 6.37 & 55,417 & $\begin{array}{l}\text { TIPMDGNFFTYTR (1561.7235) } \\
\text { IFINNEWHSSVSGK (1616.7947) } \\
\text { ELGEYGFHEYTEVK (1699.7729) } \\
\text { LFVEESIYDEFVRR (1800.9046) } \\
\text { GYFIQPTVFSDVTDDMR (2005.9092) }\end{array}$ & Up \\
\hline 14 & $\begin{array}{l}\text { Electron transfer } \\
\text { flavoprotein subunit } \\
\text { alpha, mitochondrial } \\
\text { precursor }\end{array}$ & NP_001069290 & 8.77 & 35,282 & $\begin{array}{l}\text { LDVAPISDIIAIK (1366.8071) } \\
\text { ASSTSPVGISEWLDQK (1703.8366) } \\
\text { GLLPEELTPLILATQK (1735.0131) } \\
\text { LLYDLADQLHAAVGASR }(1811.9530) \\
\text { DPEAPIFQVADYGIVADLFK }(2207.1150)\end{array}$ & Down \\
\hline \multicolumn{7}{|c|}{ Others } \\
\hline 2 & $\begin{array}{l}\text { PREDICTED: } \\
\text { glyoxalase I-like }\end{array}$ & XP_001250503 & 5.81 & 21,007 & $\begin{array}{l}\text { VAWVFSR (863.4654) } \\
\text { SLDFYTR }(900.4341) \\
\text { KSLDFYTR (1028.5291) } \\
\text { GFGHIGIAVPDVHGACK (1733.8672) } \\
\text { FSLYFLAYEDKNDIPK (1961.9774) }\end{array}$ & Down \\
\hline 3 & Regucalcin & NP_776382 & 5.54 & 33,857 & $\begin{array}{l}\text { QGSLYSLFPDHHVEK (1755.8580) } \\
\text { YFAGTMAEETAPAVLER (1870.8771) }\end{array}$ & Up \\
\hline 10 & $\begin{array}{l}\text { PREDICTED: aldo-keto } \\
\text { reductase family } 1 \text {, } \\
\text { member } \mathrm{C} 1\end{array}$ & XP_001250576 & 6.60 & 37,644 & $\begin{array}{l}\text { FAIEVGFR }(937.5022) \\
\text { QTPALVALR }(967.5815) \\
\text { REDIFYTSK (1157.5717) } \\
\text { SHDIVLVAYGALGAQR }(1668.8947) \\
\text { VWSTFLRPELVRPALEK }(2040.1520) \\
\text { LNDGHFIPVLGFGTFAPPEVPK }(2351.2314)\end{array}$ & Up \\
\hline 12 & $\begin{array}{l}\text { Glutathione S-transferase } \\
\text { Mu } 1\end{array}$ & NP_787019 & 6.90 & 25,789 & $\begin{array}{l}\text { RPWFAGDK }(975.4926) \\
\text { LTQSNAILR }(1014.5822) \\
\text { LLLEYTDTNYEER }(1657.7835)\end{array}$ & Up \\
\hline
\end{tabular}

MAIDI-TOF/TOF, Matrix-assisted laser desorption ionization/time of flight; SARA, subacute ruminal acidosis.

${ }^{1}$ Number of the protein spots in the gel.

${ }^{2}$ Accession number in National Center for Biotechnology Information.

${ }^{3}$ The sequences of all the identified peptides with the corresponding $\mathrm{m} / \mathrm{z}$ ratio in brackets.

${ }^{4}$ The expression of high-concentrate group compared with high-forage group. 
protein metabolism, elongation factor $\mathrm{Tu}(\mathrm{EF}-\mathrm{Tu})$, glutamate dehydrogenase 1 (GLDH), glutathione $\mathrm{S}$ transferase and adenosylhomocysteinase were up-regulated while $26 \mathrm{~S}$ protease regulatory subunit 7 and serum albumin precursor were down-regulated in $\mathrm{HC}$ group. At the same time, glutathione S-transferase and cytochrome b5 were also involved in oxidative stress. These results hinted that SARA had a key effect on substance metabolism in liver.

\section{DISCUSSION}

In ruminants, the change of rumen $\mathrm{pH}$ is related to prevalent consumption of rapidly fermentable carbohydrates, and authors generally define SARA based on ruminal $\mathrm{pH}$ values (DeVries et al., 2009). But the average $\mathrm{pH}$ over a day is sometimes considered as a poor indicator of SARA (Sauvant et al., 1999), because it does not reflect the large daily fluctuations in pH (Dijkstra et al., 1993; Dragomir et al., 2008). Several authors have pointed out the necessity of analyzing $\mathrm{pH}$ fluctuations (Nocek, 1997; Beauchemin et al., 2001), and the time spent under a $\mathrm{pH}$ threshold. We opted to use time below pH 5.6 as the cut-off point for SARA, as in Krause and Oetzel, because it allowed us to detect SARA in goats which were fed with a concentrate: forage ratio of 60:40, in line with previous studies using similar diets (Krause and Oetzel, 2005). The goats ate all the feeds provided, thus keeping concentrate: forage ratios of 60:40 and 40:60. We recorded that the time when $\mathrm{pH}<5.6$ was about $4 \mathrm{~h}$ in goats fed with $\mathrm{HC}$ diet over 2 successive days. So we determined that SARA was induced successfully by a concentrate: forage ratio of 60:40.

The SARA has a prolonged influence on production performance. It has long been assumed that SARA causes milk fat depression (Nocek, 1997; Kleen et al., 2003; Stone, 2004). Experimentally induced SARA, either by adding grain pellets to the diet or by replacing alfalfa hay with alfalfa pellets, reduced milk fat percentage but increased milk protein percentage (Fairfield et al., 2007). Currently, the research concerning SARA are focused on the physiopathology of SARA (Nocek, 1997; Kleen et al., 2003). Our study applied 2-DE technology to examine liver protein profiles of mid-lactating goats under different dietary patterns and identified 15 differentially expressed proteins by MAIDI-TOF/TOF. The results indicated that glucose, lipid and protein catabolism were enhanced when SARA occurred. Changes of some of the proteins were well correlated with previous findings by different means. For example, alpha enolase (spot 7) is the glycolytic enzyme that catalyzes the production of phosphoenolpyruvate from 2-phosphoglycerate. Phosphoenolpyruvate carboxykinase (spot 15) catalyzes the rate-limiting step in hepatic gluconeogenesis and adipose glyceroneogenesis. The up- regulation of alpha enolase and the down-regulation of PEPCK which are involved in glycolysis and gluconeogenesis showed that gluconeogenesis was inhibited and glycolysis was strengthened, namely carbohydrate mainly participated in oxidation and energy supply in liver when SARA occurred.

This study also inferred that lipid catabolism could be enhanced when SARA occurred, as shown by the profiles of spots 1 and 11 (Table 2 and Figure 3). Cytochrome b5 is known to function as an electron transfer component in a number of oxidative pathways, including the anabolic metabolism of fats and steroids. The cytochrome $b 5$ electron-transport system has recently been implicated in fatty acid desaturation reactions in isolated microsomes (Porter, 2002; Schenkman and Jansson, 2003). Acyl-CoA synthetase is a crucial enzyme that facilitates the uptake and permits the metabolism of intracellular lipids. And the enzyme catalyzes the first step of fatty acid metabolism by converting inactive fatty acids into active acyl CoA derivatives (Schoonjans et al., 1995). Thus it was possible that more energy was required and the mobilization of liver fat was enhanced when SARA occurred.

The observation of up-regulation of spots 5, 8, 13 and down-regulation of spots 4 and 6 which participated in protein metabolism in SARA liver was consistent with the previous theories (Lapierre and Lobley, 2001). Elongation factor Tu is a guanosine triphosphate (GTP)-binding protein that is crucial for protein biosynthesis. In the GTP-bound form of the molecule, EF-Tu binds tightly to aminoacyltRNA, forming a ternary complex that interacts with the ribosomal acceptor site. During this interaction, GTP is hydrolyzed, and EF-Tu-GDP is released (Kjeldgaard et al., 1993). The catalytic activities of adenosylhomocysteinase have an important effect in controlling the expression of intra-cellular Adohcy as well as regulating transmethylation, transsulfuration and purine metabolism, especially biological methylation. If the activity of adenosylhomocysteinase is decreased or inhibited, the metabolism of protein and nucleic acid will be affected (Palmer and Abeles, 1979). In our experiment, the upregulation of EF-Tu and adenosylhomocysteinase indicated that liver protein synthesis was enhanced when SARA occurred, which was likely to compete for raw materials of lacto protein. Spot 13 was identified as GLDH, which is the key enzyme of amine acid catabolism. The up-regulation of spot 13 in SARA liver enhanced deamination of glutamic acid, namely, amine acid catabolism was accelerated. This would make oxidation and energy supply of amine acid possible, on the other hand, would degrade the content of lutamic acid and increase the consumption of amine acid.

Calreticulin (spot 3 ) is a major endoplasmic reticulum $\mathrm{Ca}^{2+}$ binding chaperone with multiple functions and is 
involved in a variety of cellular signaling pathways, such as those involved in innate immunity, adipocyte differentiation, apoptosis, and cellular stress responses (Obeid et al., 2007; Yan et al., 2011). Calreticulin also plays a crucial role in regulating $\mathrm{Ca}^{2+}$ intracellular homeostasis (Wang et al., 2012). Recent study also showed that the overexpression of regucalcin could suppress cell death and apoptosis induced by stimulation of intracellular signaling-related factors in cloned rat hepatoma H4-II-E cells (Izumi and Yamaguchi, 2004). At the same time, some of the spots were matched to proteins related to oxidative stress, such as GST and cytochrome b5. It inferred that anti-oxidative stress of liver occurred in the activation state to resist the injury of SARA. Further studies would be required to discriminate all these processes.

In summary, this proteomic study indicates an adaptation of protein expression in liver to SARA induced by a HC diet. The results suggested that carbohydrate, lipid and amine acid in the liver mainly participated in oxidation and energy supply when SARA occurred, which possibly consumed excessive precursors involved in milk protein and milk fat synthesis. At the same time, characterization of proteome changes in the liver between HF group and HC group could serve as a model for future studies in elucidating the metabolism pathways of liver when SARA occurred.

\section{ACKNOWLEDGMENTS}

The authors declare that there is no conflict of interest is regarding the publication of this paper. This project was sponsored by grants from the China National Basic Research Program Foundation (Project No. 2011CB100802); Priority Academic Program Development of Jiangsu Higher Education Institutions; and Graduate Students' Innovative Projects of Jiangsu Higher Education Institutions (Project No. CXLX 13-291).

\section{REFERENCES}

AlZahal, O., B. Rustomo, N. E. Odongo, T. F. Duffield, and B.W. McBride. 2007. Technical note: A system for continuous recording of ruminal ph in cattle. J. Anim. Sci. 85:213-217.

Beauchemin, K. A., W. Z. Yang, and L. M. Rode. 2001. Effects of barley grain processing on the site and extent of digestion of beef feedlot finishing diets. J. Anim. Sci. 79:1925-1936.

Bergman, E. N. 1990. Energy contributions of volatile fatty acids from the gastrointestinal tract in various species. Physiol. Rev. 70:567-590.

Bradford, M. M. 1976. A rapid and sensitive method for the quantitation of microgram quantities of protein utilizing the principle of protein-dye binding. Anal. Biochem. 72:248-254.

Brossard, L., C. Martin, and B. Michalet-Doreau. 2003. Ruminal fermentative parameters and blood acido-basic balance changes during the onset and recovery of induced latent acidosis in sheep. Anim. Res. 52:513-530.

Candiano, G., M. Bruschi, L. Musante, L. Santucci, G. M. Ghiggeri, B. Carnemolla, P. Orecchia, L. Zardi, and P. G. Righetti. 2004. Blue silver: A very sensitive colloidal coomassie g-250 staining for proteome analysis. Electrophoresis 25:1327-1333.

Chen, J., X. Tang, Y. Zhang, H. Ma, and S. Zou. 2010. Effects of maternal treatment of dehydroepiandrosterone (dhea) on serum lipid profile and hepatic lipid metabolism-related gene expression in embryonic chickens. Comp. Biochem. Physiol. B. Biochem. Mol. Biol. 155:380-386.

DeVries, T. J., K. A. Beauchemin, F. Dohme, and K. S. Schwartzkopf-Genswein. 2009. Repeated ruminal acidosis challenges in lactating dairy cows at high and low risk for developing acidosis: Feeding, ruminating, and lying behavior. J. Dairy Sci. 92:5067-5078.

Dijkstra, J., H. Boer, J. Van Bruchem, M. Bruining, and S. Tamminga. 1993. Absorption of volatile fatty acids from the rumen of lactating dairy cows as influenced by volatile fatty acid concentration, ph and rumen liquid volume. Br. J. Nutr. 69:385-396.

Dragomir, C., D. Sauvant, J. L. Peyraud, S. Giger-Reverdin, and B. Michalet-Doreau. 2008. Meta-analysis of 0 to $8 \mathrm{~h}$ post-prandial evolution of ruminal ph. Animal. 2:1437-1448.

Fairfield, A. M., J. C. Plaizier, T. F. Duffield, M. I. Lindinger, R. Bagg, P. Dick, and B. W. McBride. 2007. Effects of prepartum administration of a monensin controlled release capsule on rumen $\mathrm{ph}$, feed intake, and milk production of transition dairy cows. J. Dairy Sci. 90:937-945.

Fella, K., M. Gluckmann, J. Hellmann, M. Karas, P. J. Kramer, and M. Kroger. 2005. Use of two-dimensional gel electrophoresis in predictive toxicology: Identification of potential early protein biomarkers in chemically induced hepatocarcinogenesis. Proteomics 5:1914-1927.

Gozho, G. N., J. C. Plaizier, D. O. Krause, A. D. Kennedy, and K. M. Wittenberg. 2005. Subacute ruminal acidosis induces ruminal lipopolysaccharide endotoxin release and triggers an inflammatory response. J. Dairy Sci. 88:1399-1403.

Izumi, T. and M. Yamaguchi. 2004. Overexpression of regucalcin suppresses cell death in cloned rat hepatoma h4-ii-e cells induced by tumor necrosis factor-alpha or thapsigargin. J. Cell. Biochem. 92:296-306.

Jianzhen, H., M. Haitian, Y. Liming, and Z. Sixiang. 2007. Developmental changes of protein profiles in the embryonic sanhuang chicken liver. J. Vet. Med. A. Physiol. Pathol. Clin. Med. 54:464-469.

Kleen, J. L., G. A. Hooijer, J. Rehage, and J. P. Noordhuizen. 2003. Subacute ruminal acidosis (sara): A review. J. Vet. Med. A. Physiol. Pathol. Clin. Med. 50:406-414.

Kjeldgaard, M. Nissen, P. Thirup, and S. Nyborg. 1993. The crystal structure of elongation factor EF-Tu from Thermus aquaticus in the GTP conformation. Structure 1:35-50.

Krause, K. M. and G. R. Oetzel. 2005. Inducing subacute ruminal acidosis in lactating dairy cows. J. Dairy Sci. 88:3633-3639.

Lapierre, H. and G. E. Lobley. 2001. Nitrogen recycling in the ruminant: A review. J. Dairy Sci. 84:E223-E236.

Nocek, J. E. 1997. Bovine acidosis: Implications on laminitis. J. 
Dairy Sci. 80:1005-1028.

Obeid, M., A. Tesniere, T. Panaretakis, R. Tufi, N. Joza, P. van Endert, F. Ghiringhelli, L. Apetoh, N. Chaput, C. Flament, E. Ullrich, S. de Botton, L. Zitvogel, and G. Kroemer. 2007. Ectocalreticulin in immunogenic chemotherapy. Immunol. Rev. 220:22-34.

Palmer, J. L., R. H. Abeles. 1979. The mechanism of action of Sadenosylhomocysteinase. J. Biol. Chem. 254:1217-1226.

Porter, T. D. 2002. The roles of cytochrome b5 in cytochrome p450 reactions. J. Biochem. Mol. Toxicol. 16:311-316.

Sauvant, D., F. Meschy, and D. Mertens. 1999. Components of ruminal acidosis and acidogenic effects of diets. Prod. Anim. 12:49-60

Schenkman, J. B. and I. Jansson. 2003. The many roles of cytochrome $b_{5}$. Pharmacol. Ther. 97:139-152.
Schoonjans, K., M. Watanabe, H. Suzuki, A. Mahfoudi, G. Krey, W. Wahli, P. Grimaldi, B. Staels, T. Yamamoto, and J. Auwerx. 1995. Induction of the acyl-coenzyme a synthetase gene by fibrates and fatty acids is mediated by a peroxisome proliferator response element in the c promoter. J. Biol. Chem. 270:19269-19276.

Stone, W. 2004. Nutritional approaches to minimize subacute ruminal acidosis and laminitis in dairy cattle. J. Dairy Sci. $87: 13-26$

Wang, W. A., J. Groenendyk, and M. Michalak. 2012. Calreticulin signaling in health and disease. Int. J. Biochem. Cell Biol. 44: 842-846.

Yan, Q., J. E. Murphy-Ullrich, and Y. Song. 2011. Molecular and structural insight into the role of key residues of thrombospondin-1 and calreticulin in thrombospondin-1calreticulin binding. Biochemistry 50:566-573. 